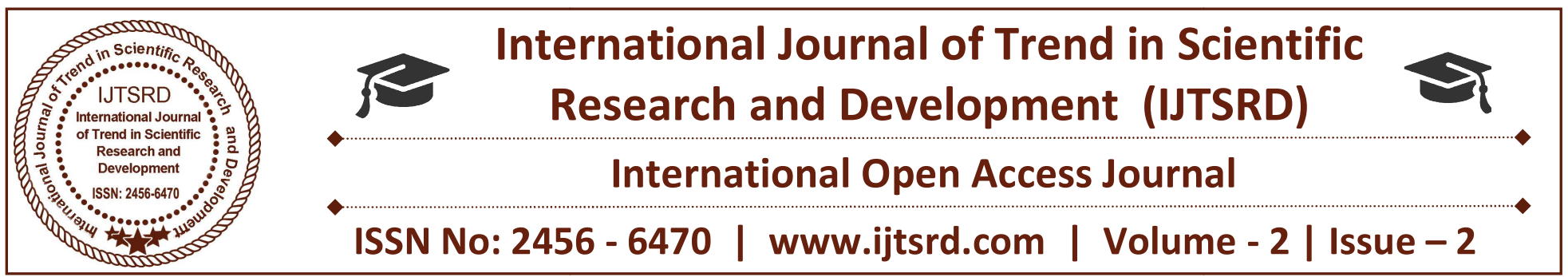

\title{
Pterocarpus Marsupium Importance in Various Activities - A Review
}

\author{
Dr. Siva Rami Reddy E \\ Research Scholar, Faculty of Homoeopathy, \\ Tantia University, Sri Ganganagar, Rajasthan, India
}

\begin{abstract}
Extracts of Pterocarpus Marsupium were prepared using methods like infusion, maceration, decoction and percolation. Several chemical constituents like pterostilbene, epicatechin, pterosupin, marsupin, tannins, pentosan, propterol, isoflavonoid glycol, liquiritigenin etc. were identified and isolated. Pterocarpus Marsupium Roxb. (Fabaceae) is one such herbal drug which finds its place in AYUSH. Nature has bestowed this herb with a high versatility due to which it exhibits a wide range of Pharmacological actions. Pterocarpus marsupium commonly known as Indian Kino tree or Asana or Vijayasar is a large deciduous tree found in the subtropical regions of the world.
\end{abstract}

Keywords: Pterocarpus Marsupium, Phytochemical, Pharmacological, Anti diabetic

\section{Introduction}

The history of herbal medicine is as old as human civilization and even in the current scenario; near about $75-80 \%$ of the world population relies on the medicinal plants for primary health care ${ }^{[1]}$. The reason being that they are easily available, cheap and devoid of side effects. ${ }^{[2]}$ WHO states that the herbs are used two to three times more than the conventional drugs as remedies for various ailments [3]. Various plants have been used since ages as medicine. Pterocarpus Marsupium is one such plant which has proved itself as versatile plant with a broad spectrum of pharmacological actions. It has been mentioned in various traditional systems of medicine like Ayurvedic, Unani and Homeopathic systems of medicine ${ }^{[4]}$. Pterocarpus Marsupium Roxb belongs to Fabaceae (Pterocarpus Marsupium) known as Indian Kino Tree or Malabar Tree in English; Vijayasar or Bija in Hindi and Asana in Sanskrit is indigenous to India, Nepal and Sri Lanka ${ }^{[5,6]}$. It is found specifically in the areas of the Western Ghats, in the Karnataka-Kerala region, in the states of Gujarat, Madhya Pradesh, Bihar and Orissa. [7] Pterocarpus Marsupium fined its place in the Rasayans group of Ayurveda ${ }^{[8]}$. Due to the exploitation of the tree for its timber and medicinal bark, its population is decreasing in the wild and thus, it has been mentioned in the red data book ${ }^{[9]}$. Pterocarpus marsupium is a medium to large sized deciduous tree growing upto $30 \mathrm{~m}$ in height and $2.5 \mathrm{~m}$ in girth ${ }^{[10]}$, with dark brown to grey bark having superficial fissures; leaves compound and imparipinnate; flowers yellow in terminal panicles; fruit circular, flat, winged pod; seed convex \& bony. ${ }^{[11]}$ Flowering and fruiting duration of the tree is from March to June ${ }^{[12]}$. The major phytoconstituents of Pterocarpus Marsupium are pterostilbene and marsupin. [13,14] Others are liquirtigenin, iso liquirtigenin, pterosupin, p-hydroxybenzaldehyde, 7, 4'dihydroxyflavone ${ }^{[14]}$, propterol ${ }^{[15]}$, marsupol ${ }^{[16]}$, carsupin [17] and so on. Different plant parts of Pterocarpus Marsupium have been used for various diseases like leaves for boils, sores, skin diseases and stomach pain; flowers for fever; Gum Kino for diarrhea, dysentery, leucorrhoea etc. and bark as astringent \& for toothache. ${ }^{[18,19]}$ Decoctions of bark and resin have been used traditionally for the treatment of tumours of the gland, urethral discharges 
and as abortifacient. ${ }^{[20]}$ The heartwood possesses astringent, anti inflammatory, anti diabetic and anodyne properties ${ }^{[21]}$.

Fig 1: Different Stages of Pterocarpus marsupium

(A) Flower in Stage

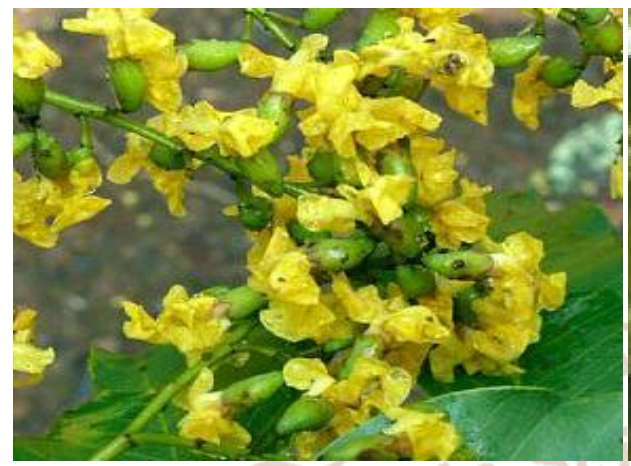

(C) Mature Fruit Stage

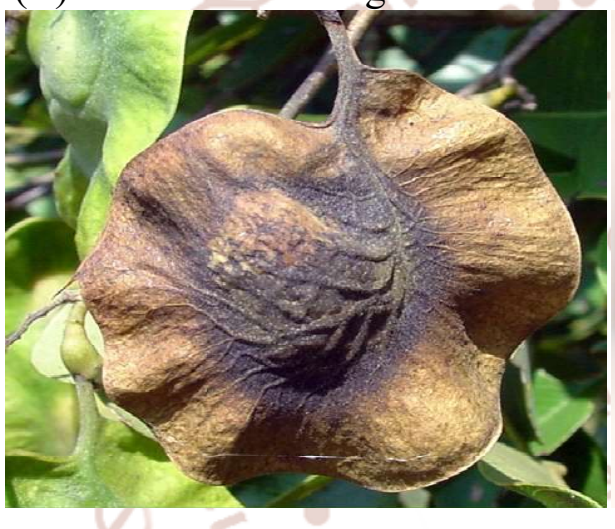

(B) Fruiting Stage

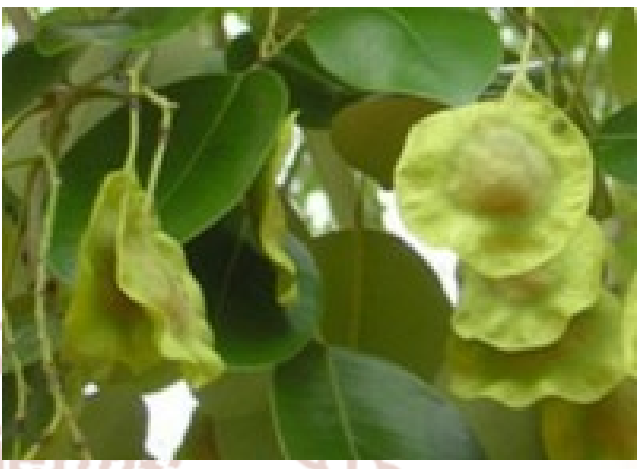

(D) Seeds of Pterocarpus Marsupium

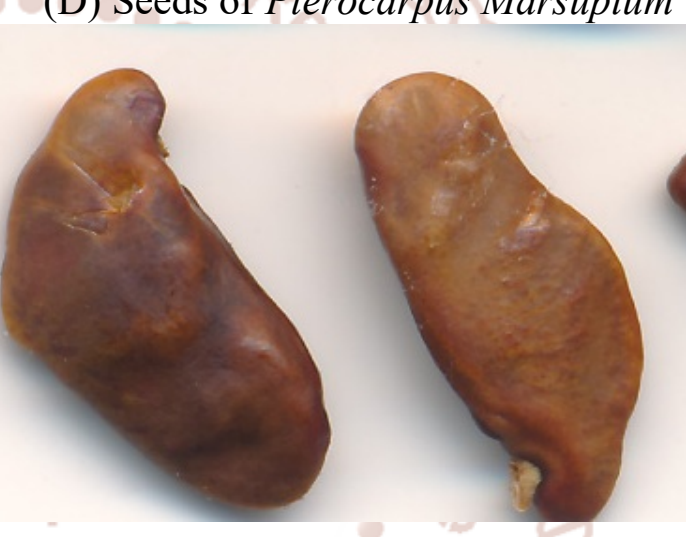

\section{History and Distribution}

This plant is widely distributed from Western Ghats in the Karnataka, kerala, Gujarat, Madhya Pradesh, Bihar, Goa, Andhra Pradesh, Maharashtra, Rajasthan and orissa region. It is belongs to fabaceae and bija is native to India, Nepal and Sri lanka. ${ }^{[22-28]}$

\section{Botanical Description}

Pterocarpus Marsupium Roxb (Fabaceae) is a deciduous tree about $90 \mathrm{ft}$ or more high. Leaves are 3 to 5 inch long, have 5-7 leaflets, oblong, margin wavy and obtuse. The petioles are round, smooth and waved from leaflet to leaflet, 5 or 6 inches long and there are no stipules. Flower about $1.5 \mathrm{~cm}$ long, very numerous, white with a small tinge of yellow. The heartwood of this tree is golden yellow. Tree bark yields a reddish gum. Stamens are 10, united near the base, but soon dividing into two parcels of 5 each, anthers are globose and 2-lobed.The legume, which is borne on a long petiole, is three-fourths orbicular, the upper remainder, which extends from the pedicel to the remainder of this style, is straight, the whole surrounded with a waved, veiny, downy, membranous wing, swelled, rugose, woody in the center, where the seed is lodged and not opening. ${ }^{[2,30]}$ Fruit is circular, flat, winged pod. Seed is convex and bony. ${ }^{[31]}$ It gives flowers and fruits in the month of March to June. ${ }^{[32]}$

It is of moderate size to large tree. The height ranges from 15 to 30 meters. The stem is stout and crooked with widely spreading branches. The bark is thick and dark brown to grey in colour. Leaves are compound and imparipinnate. Leaflets are 5-7, coriaceous, oblong, obtuse, emarginated or even bilobed at the apex and glabrous on both surfaces. The petioles are round, smooth and waved from leaflet to leaflet, 5 or 6 inches long and there are no stipules. Panicles are terminal and very large; ramifications are bifarious, like the leaves. Peduncles and pedicels are round and a little downy. Bracts are small, caduceus, solitary below each division and subdivision of the panicle. 
The flowers are very numerous, white, with a small tinge of yellow. Vexillum is with a long, slender claw, very broad; sides refluxed, waved, curled and veined; keel is two pettled, adhering slightly for a little way near the middle, waved, etc., same as the vexillum. Stamens are 10, united near the base, but soon dividing into two parcels of 5 each; anthers are globose and 2 lobed. Ovary is oblong, pedicelled, hairy, generally 2 celled; cells are transverse and 1 seeded. Style is ascending. The legume, which is borne on a long petiole, is three-fourths orbicular, the upper remainder, which extends from the pedicel to the remainder of the style, is straight, the whole surrounded with a waved, veiny, downy, membraneous wing, swelled, rugose, woody in the center, where the seed is lodged and not opening; generally one but sometimes 2 celled. Seeds are single and reniform. ${ }^{[33,34]}$ Drug consists of heartwood of Pterocaipus marsupium. It consists of irregular pieces of variable size and thickness. It is golden yellowish brown in colour with darker streaks.

It is very hard and brittle. In water it gives yellow coloured solution with blue fluorescence. Transverse section shows alternating bands of larger and smaller polygonal cells consisting of tracheids, fibre tracheids, xylem parenchyma and transversed by xylem rays. Xylem vessels are throughout distributed. Tyloses filled with tannins are present. Tracheids are long, thick walled with tapering ends and simple pits. Xylem parenchyma cells are rectangular with simple pits and xylem rays are uni to biseriate. The calcium oxalate crystals are present and the starch is absent.

\section{Phytochemical:}

Pterocaipus Marsupium phytochemical are pterosupin, pterostilbene, liquirtigenin, isoliquiritigenin, epicatechin, kinoin, kinotannic acid, kino red, beta eudesmol, carsupin, marsupol and marsupinol. [36] Isolation of components from the aqueous extract of Pterocaipus Marsupium. heartwood yielded a few novel flavonoid C-glycosides: 2,6hydroxy-2-(4-hydroxybenzyl)-benzofuran-7-C-bdglucopyranoside( 1),3-(a-methoxy-4hydroxybenzylidene)-6- hydroxyl benzo-2(3H)furanone-7-C-b-d-glucopyranoside(2), 2-hydroxy-2-phydroxybenzyl-3(2H)-6 hydroxybenzo furanone-7-Cb-d-glucopyranoside (4), 8-(C-b-dglucopyranosyl)7,30,40-trihydroxyflavone (5) and 1,2-bis (2,4dihydroxy,3-Cglucopyranosyl)-ethanedione (6) and two known compounds C-b-d-glucopyranosyl-2,6dihydroxyl benzene (7) and sesquiterpene (8) ${ }^{[37]}$. Another new phytoconstituent 6,7,3',4tetraoxygeneted homoisoflavonoid characterized as 6hydroxy-7-O-methyl-3- (3-hydroxy-4-Omethylbenzyl) chronan-4-one was isolated from ether soluble fractions of Pterocarpus marsupium heartwood while a flavonol glycoside from the roots [38]. An isoaurone C-glycoside was obtained from the aqueous ol extract of Pterocarpus Marsupium heartwood ${ }^{[39]}$. Two interconvertible diasteriomeric epimers $2 \alpha / 2 \beta$-hydroxy-2-Phydroxybenzyl- $3(2 \mathrm{H})$ benzofuranone-7-C- $\beta$-D-glucopyranoside have also been reported ${ }^{[40]}$.

Figure 2: Chemical structure of Ptericarpus Marsupium

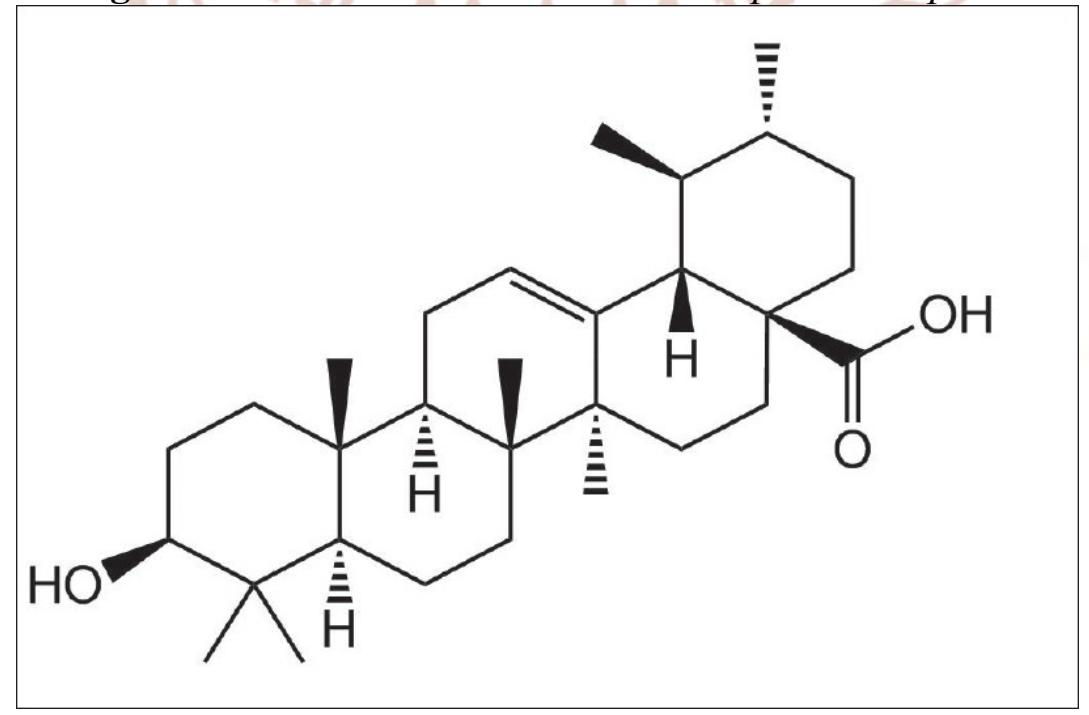


The findings of various indicated that Pterocarpus Marsupium contains numerous polyphenolic compounds ${ }^{[41]}$, terpenoids ${ }^{[42]}$, fluorescent pigment, phenol glucosides ${ }^{[43]}$ and pterostilbene ${ }^{[44]}$.

\section{Pharmacological activities:}

\section{A. Antidiabetic activity:}

The prevalence of diabetes mellitus is rapidly increasing all over the world, and it has become a global public health crisis. ${ }^{[4]}$ According to International Diabetes Federation, 387 million people worldwide have diabetes and it is projected to reach 592 million by $2035 .^{[46]}$ Diabetes mellitus increases with aging. In 2010, the prevalence of diabetes mellitus in the United States was estimated to be $0.2 \%$ in individuals aged $<20$ years and $11.3 \%$ in individuals aged $>20$ years. In individuals aged $>65$ years, the prevalence of diabetes mellitus was $26.9 \%$. Diabetes is a major cause of mortality, but several studies indicated that diabetes is likely unreported as a cause of death. In the United States, diabetes was listed as the 7th leading cause of death in 2007; a recent estimate suggested that diabetes was the fifth leading cause of death worldwide and was responsible for almost 4 million deaths in 2010. ${ }^{[47]}$

Hypoglycaemic effects of the Petrocarpus / M heartwood and bark are studied extensively. Many of these studies were conducted in diabetes induced rats and there are some reports on the clinical trials conducted with Pterocaipus Marsupium. Some of these studies have addressed the mechanism of action and toxicity of the extracts as well. Evidence for the $b$ cell regeneration in the pancreas ${ }^{[48,49]}$, insulin release ${ }^{[50,51]}$, insulin like action ${ }^{[52,53]}$, increased expression of glucose transporter [54], inhibition of digestive enzymes amylase and glucosidase (by the latex) ${ }^{[55,56]}$ are some of the mechanisms identified. Furthermore, evidence on protective effects such as antioxidant effects [57], antidyslipidaemic effects ${ }^{[57-59]}$ and evidence for antiglycation effects of the latex are available ${ }^{[60,61]}$. Several compounds responsible for the antidiabetic effects of Pterocaipus Marsupium have been revealed. Many investigations have focused on pterostilbene and (-) epicatechin which were recognized as two major compounds responsible for the antidiabetic effects of heartwood and bark respectively.
Ethanol and aqueous extracts of Pterocaipus Marsupium bark were investigated in several studies. In one study, ethanol extracts of Pterocarpus Marsupium bark $(150 \mathrm{mg} / \mathrm{kg})$ administered daily for a period of 14 days to alloxan induced diabetic rats caused a reduction in blood glucose. Another study revealed that various sub fractions of the alcohol extract of Pterocarpus Marsupium bark were effective as antidiabetic agents in alloxan induced diabetic rats and the butanol subfraction was found to be most effective. Aqueous extracts of Pterocaipus marsupium bark $(1 \mathrm{~g} / \mathrm{kg} /$ day $)$ given to rats fed with a fructose rich diet for 30 days lowered the serum glucose concentration compared to the group which did not receive the extract . Aqueous extract of Pterocaipus Marsupium bark lowered blood glucose and improved glucose tolerance with no side effects in alloxaninduced diabetic rats ${ }^{[62]}$. In another study conducted with alloxan induced diabetic rats, hypoglycaemic effects of a 21 day dose of aqueous extract of the Pterocaipus marsupium stem bark (1 g/kg) was demonstrated ${ }^{[63]}$.

Studies have revealed that ethanol and aqueous extracts of Pterocaipus marsupium heartwood, their sub fractions and epicatechin from Pterocaipus marsupium bark increase insulin release. Ethanol extract of Pterocaipus marsupium heartwood given for 10 days increased serum insulin concentration in streptozotocin-induced diabetic rats. Antidiabetic constituents in the aqueous extract of Pterocaipus marsupium heartwood were fractionated using bioassay guided fractionation in a study and a high molecular weight fraction $(>10<30 \mathrm{kDa})$ isolated has shown potent insulinotrophic and insulin like properties. The same study revealed that Pterocaipus marsupium stimulated the insulin secretion from the mouse pancreas in a concentrationdependent manner in vitro.

Increase in glucose uptake by peripheral tissues is a major event which lowers the blood glucose concentration during fed state. Skeletal muscle and adipose tissue are major tissues which respond to insulin mediated increase in glucose uptake. Studied the effects of five phenolic compounds isolated from $\mathrm{n}$ butanol fraction of the ethanolic extract of Pterocaipus Marsupium heartwood on 2-deoxyglucose uptake by mouse skeletal muscle cells (C2C12). When incubated for $24 \mathrm{~h}$ of which the final $3 \mathrm{~h}$ prior of the assay were in serum free media, four 
phenolic compounds namely vijayoside, pteroside, marsuposide and pterosupol $(10 \mu \mathrm{M} / \mathrm{ml})$ increased the glucose uptake in basal and insulin stimulated cells in a concentration dependent manner.

\section{B. Anti hyperinsulinaemic and anti hyper triglyceridaemic activity:}

The aqueous extract of Pterocarpus marsupium bark substantially prevented insulin resistance (hyperinsulinaemia) and hypertriglyceridaemia ${ }^{[64]}$. In another study, Jahromi and Ray administered the ethyl acetate extract of heartwood of Pterocarpus marsupiumin rats for 14 consecutive days. The results proved that there is a significant reduction of serum triglyceride, total cholesterol, LDL and VLDL cholesterol without any significant effect on the level of HDL cholesterol ${ }^{[65]}$.

\section{Hepatoprotective activity}

Rane and Grampurohit N D Methanolic extract of $P$. marsupium possesses hepatoprotective activity. In methanol extract treated animals the toxic effect of CCL4 was controlled significantly by distortion of the level of serum bilirubin protein and enzymes as compared to normal and standerd drug. Silymarin treated groups. Histology of liver secretions of the animals treated with the extracs showed the presence of normal hepatic cords, absence of necrosis and fatty filtration which further evident the hepatoprotective activity. [66]

\section{Antibacterial Activity}

Antimicrobial activity of bark and leaf extracts from $P$. marsupium. Hexane, ethyl acetate and methanol extracts were tested against four selected Gram positive and Gram negative bacteria. ${ }^{[67,68]}$ In vitro, it inhibits Pseudomonas aeruginosa, Streptococcus pyrogens and Staphylococcus aureus. Ethyl and methanol extracts were more sensitive to the bacteria than extracts made out of hexane. Both the extracts exhibited concentration dependent variation in their anti bacterial activity. Similar observations have been reported where it has been showed that ethanol extracts of $P$. marsupium exhibited significant antiulcer and antioxidant properties in rats. ${ }^{[69]}$

\section{E. Anti hyperlipidemic Activity}

Numerous natural products including Pterocarpus marsupium have been screened for their hypolipidemic potential. ${ }^{[70]}$ The ethanolic extract of
Pterocarpus marsupium heartwood and its flavonoid phytoconstituents marsupin, pterosupin, and liquiritigenin have shown anti hyperlipidemic effect. The experimental observations proved that the extract was able to reduce serum triglyceride, total cholesterol, LDL and VLDL cholesterol without any significant effect on the level of HDL cholesterol. It was also shown that liquiritigenin and pterosupin lowered the serum cholesterol, LDL cholesterol and antherogenic index while pterosupin also reduced the triglyceride level. ${ }^{[71]}$ Another investigation proved the utility of aqueous extract of Pterocarpus marsupium bark in hypertriglyceridaemia. ${ }^{\text {[72] }}$

\section{F. Anti inflammatory Activity}

Pterocarpus marsupium is also a potent antiinflammatory agent. Extract containing pterostilbene was investigated for its PGE2 inhibitory activity in LPS stimulated PBMC and for $\mathrm{COX}-1 / 2$ selective inhibitory activity ${ }^{[73,74]}$. Aqueous extract of Pterocarpus marsupium at doses of $100 \mathrm{mg} / \mathrm{kg}$ and $200 \mathrm{mg} / \mathrm{kg}$ was found to reduce the elevated inflammatory cytokine, tumor necrosis factor TNF- $\alpha$ level in type 2 diabetic rats. ${ }^{[75]}$ The methanolic and aqueous extract of Pterocarpus Marsupium stem bark, both at the doses of $100 \mathrm{mg} / \mathrm{kg}$ showed positive results for anti inflammatory activity in carrageenan induced rat paw oedema model. ${ }^{[76]}$ The herbal hydrogels containing hydro alcoholic extracts of Pterocarpus marsupium, Pterocarpus santalinus and Glycyrrhiza glabra exhibited significant anti inflammatory activity $(43.70 \%)$ when compared with the standard (17.03\%). [77]

\section{G. Microbicidal Activity}

Methanolic extract of Pterocarpus marsupium has shown microbicidal activity. Bactericidal potential of methanolic extract of stem bark (Apical bark, middle bark and Mature bark) of Pterocarpus marsupium was evaluated with respect to pathogenic bacteria Bacillus subtilis, Staphylococcus aureus, Escherichia coli, Pseudomonas aeruginosa, Klebsiella pneumoneae, Salmonella typhi, Proteus mirabilis and Micrococcus $s p$. Thus, in the pharmacological point of view, it is important to study the biochemistry of apical bark in order to isolate and screen the new pharmacological active principals which can be useful in designing of new drugs active against various infectious micro organisms like bacteria. ${ }^{[78]}$ 


\section{H. Anti cataract Activity}

Aqueous extract of Pterocarpus marsupium has shown anti cataract activity. Aqueous extract had significantly decreased opacity index in the alloxan induced diabetic rats. ${ }^{[79]}$

\section{Conclusion:}

In developing countries, providing modern healthcare facilities is still in infancy. The Pterocarpus Marsupium carried out an importance from the ancient times to cure mankind against various disease conditions. These studies play the drug as a novel candidate for bioprospection and drug development for treatment of diseases such as cancer, diabetes, cataract, ulcer, dementia, diarrhoea and various disorders. The medicinal applications of this plant are countless and investigations still remain and carry out in relatively new areas of its function. By the isolation of various phytochemicals it enables to exploit its therapeutic value and plays a major role in modern system of medicine and it requires further exploitation.

\section{Financial Support and sponsorship Nil}

\section{Conflicts of interest}

None declared.

\section{REFERENCES:}

1. Kamboj VP. Current Science, 2000; 78:35-39.

2. Gupta LM, Raina R. Current Science.1998; 75:897-900.

3. Evans M. A guide to herbal remedies. Orient Paperbacks 1994:24-30.

4. Badkhane Y, Yadav AS, Sharma AK, Raghuwanshi DK, Uikey SK, Mir FA, Lone SA, Murab T. Int. J. Adv. In Pharm Sci, 2010; 1:350357.

5. Gamble JS. Flora of the Presidency of Madras, Adlard and Sons Ltd, London, UK, 1935.

6. Matthew KM. The Flora of Tamil Nadu Carnatic, St. Josephs College, Tiruchirapalli, India. 1983.

7. Palanisamy D, Kannan E, Bhojraj G. Asian J of Trad Med, 2007; 2(2):52-57.

8. Agnivesha. Prameha Chikitsa: Charaka Samhita. fifth ed., Choukamba Sanskrita Samsthana, Varanasi, 2001; 446- 447.
9. Ramya S, Kalayansundaram M, Kalaivani T, Jayakumararaj R. Ethnobotanical Leaflets, 2008; 12:1029-1034.

10. Saldanha CJ. Flora of Karnataka, Oxford, IBH Publishing, 1984; 1:21.

11. Warrier PK. Indian Medicinal Plants: A compendium of 500 species, 1995, 3, 280.

12. Yadav SR, Sardesai MM. Flora of Kolhapur District, 2002, 87.

13. Mathew J, Subba Rao AV, Subba Rao NV. Curr Sci, 1977; 46:337-338.

14. Maurya R, Ray AB, Duah FK, Slatkin DJ, Schiff PL. J Nat Prod, 1984; 4:179-181.

15. Subba Rao AB, Mathew J, Sankaran AVB. Phytochemistry, 1984; 23(4):897-898.

16. Subba Rao V, Mathew J. Phytochemistry, 1982; 2:1837- 1838 .

17. Mathew J, Subha Rao AV. Phytochemistry, 1983; 22:794-795.

18. The Ayurvedic Pharmacopoeia of India, First Edition, Govt. of India, Ministry of Health and Family Welfare, Dept. of Indian System of Medicine \& Homeopathy, New Delhi 2001; 1(1):12-13.

19. Pullaiah T. Medicinal Plants of Andhra Pradesh, Regency Publications, New Delhi, India, 1999, 63.

20. Basu K. Indian Medicinal Plants, 2nd Ed, Dehradun, Jayed Press, Delhi, 1975, 828.

21. Kirtikar B. Indian medicinal Plants, 2nd Ed, New Delhi, 1987, 1:826-827.

22. Saldanha CJ. Flora of Karnataka. Oxford; IBH Publisher.1984; 1:21.

23. Palanisamy D, Kannan E, Bhojraj G. Protective and Therapeutic effects of the Indian medicinal plant Pterocarpus marsupium on D Galactosamine induced Liver damage. Asian J Tra Med. 2007.2(2):52-57.

24. Warier PK, Osmium basilicum Linn. In: Indian Medicinal Plants, Orient Longman Ltd Madras, India, 1995.

25. Chopra RM, Indigenous drugs of India. 2nd Edition, Art press, Calcutta, India, 1958, 336.

26. Sanjappa M, Checklist of the Leguminosae in south Asia. Typescript, 267.

27. Gamble JS, Flora of the Presidency of Madras. Adlard and Sons Ltd, London, UK, 1935, 451452.

28. Matthew KM. The Flora of Tamil Nadu Carnatic. St. Josephs College, Tiruchirapalli, India 1983, 229-236. Rajpal V, Standardization of botanicals, testing and extraction methods of medicinal herbs. 
International Journal of Trend in Scientific Research and Development (IJTSRD) ISSN: 2456-6470

Vol. 2, Eastern publisher, New Delhi, 2005, 296306.

29. The Ayurvedic Pharmacopeia of India. Government of India ministry of Health and Family Welfare Department of Ayush; 1, 1989, 15-17.

30. Warier $\mathrm{P} \quad \mathrm{K}$, Indian medicinal plants: A compendium of 500 species. Vol. 3, 1995,280.

31. Yadav SR, Sardesai MM. Flora of Kolhapur District. 2002, 87.

32. V. Rajpal. Standardization of Botanicals, testing and extraction methods of medicinal herbs, Eastern Publisher, New Delhi. 2005;1:296-306

33. Manish devgun, Arun nandha, Ansari, Pterocarpus marsupium- A comprehensive review phytochemistry 2009; 3(6):359-363.

34. The Ayurvedic Pharmacopoeia of India, Part -I. The Controller of Publications, Civil Lines, Delhi.1990; 1:12-13.

35. Dharshan S, Veerashekar T, Kuppast IJ, Raghu JD. Int J of Uni Phar Bio Sci, 2014; 3(6):32-41.

36. Badkhane Y, Yadav AS, Sharma AK, Raghuwanshi DK, Uikey SK, Mir FA, Lone SA, Murab T. Int. J. Adv. In Pharm Sci, 2010; 1:350357.

37. Maurya RS, Mundkinajeddu D, Handa SS, Prem PY, Mishra PK. Phytochemistry, 2004; 65:915920.

38. Yadav RN, Singh RK, Phytochemistry, 1998; 48(7):1259-1261.

39. Handa SS, Singh R, Maurya R, Satti NK, Suri KA, Suri OP. Tetrahedron Letters, 2000; 41(10):1579-1581.

40. Grover RK, Maurya R, Roy R. Tetrahedron, 2004; 60(9):2005-2010.

41. Seshadri TR. Polyphenols of Pterocarpus and Dalbergia Wood, Phytochemistry, 1972; 11:881.

42. Patil UH, Gaikwad DK. Pharmacognosy Journal. 2011; 3(20):85-87.

43. Achari B, Dutta PK, Roy SK, Chakraborty P, Sengupta J, Bandyopadhyay D, Maity JK, Khan IA, Ding Y, Ferreira D. Nat Prod J, 2012; 75(4):655-660.

44. Rimando AM, Cuendet M, Desmarchelier C, Mehta RG, Pezzuto JM, Duke SO. J Agric Food Chem, 2002; 50(12):3453-3457.

45. Hu FB. Globalization of diabetes: the role of diet, lifestyle, and genes. Diabetes Care. 2011;34(6):1249-57.

46. International Diabetes Federation. IDF Diabetes Atlas. 2015.6:12-45.
47. Powers AC. Diabetes mellitus. Harrison's Principles of Internal Medicine. 18th Edition, Volume I. New York: McGraw-Hill; 2012: 334, 2969.

48. Chakravarthy BK, Saroj G, Gambhir SS, Gode KD. Pancreatic beta cell regeneration-A novel antidiabetic mechanism of Pterocarpus marsupium roxb. Indian Journal of Pharmacology. 1980;12(2):123-127.

49. Chakravarthy BK, Gupta S, Gode KD. Functional beta cell regeneration in the islet of pancreas in alloxan induced diabetic rats by (-)epicatechin. Life Sciences. 1982; 31:2693-2697.

50. Mohankumar SK, O'Shea T, McFarlane JR. Insulinotrophic and insulin-like effects of a high molecular weight aqueous extract of Pterocarpus marsupium Roxb. hardwood. Journal of Ethnopharmacology.2012; 141(1):72-79.

51. Mishra A, Srivastava R, Srivastava SP, Gautam S, Tamrakar AK, Maurya R, et al. Antidiabetic activity of heart wood of Pterocarpus marsupium Roxb. And analysis of phytoconstituents. Indian Journal of Experimental Biology. 2013; 51(5):363-374.

52. Anandharajan R, Pathmanathan K, Shankernarayanan NP, Vishwakarma RA, Balakrishnan A. Upregulation of GLUT-4 and PPAR $\gamma$ by an isoflavone from Pterocarpus marsupium on L6 myotubes: A possible mechanism of action. Journal of Ethnopharmacology. 2005; 97(2):253-260.

53. Gayathri M, Kannabiran K. Studies on the ameliorative potential of aqueous extract of bark of Pterocarpus marsupium Roxb in streptozotocininduced diabetic rats. Journal of Natural Remedies. 2010;10(1):36-43.

54. Gaster M, Nehlin JO, Minet AD. Impaired TCA cycle flux in mitochondria in skeletal muscle from type 2 diabetic subjects: Marker or maker of the diabetic phenotype. Archives of Physiology and Biochemistry. 2012; 118(3):156-189.

55. Abesundara KJ, Matsui T, Matsumoto K. Alphaglucosidase inhibitory activity of some Sri Lanka plant extracts, one of which, Cassia auriculata, exerts a strong antihyperglycemic effect in rats comparable to the therapeutic drug acarbose. Journal of Agricultural and Food Chemistry. 2004;52(9):2541-2545.

56. Poongunran J, Perera HKI, Fernando WIT, Jayasinghe L, Sivakanesan R. $\alpha$-glucosidase and $\alpha$-amylase inhibitory activities of nine Sri Lankan 
International Journal of Trend in Scientific Research and Development (IJTSRD) ISSN: 2456-6470

antidiabetic plants. British Journal of Pharmaceutical Research. 2015; 7(5):365-374.

57. Maruthupandian A, Mohan VR. Antidiabetic, antihyperlipidaemic and antioxidant activity of Pterocarpus marsupium Roxb. in alloxan induced diabetic rats. International Journal of Pharm Tech Research. 2011; 3(3):1681-1687.

58. Grover JK, Vats V, Yadav SS. Pterocarpus marsupium extract (Vijayasar) prevented the alteration in metabolic patterns induced in the normal rat by feeding an adequate diet containing fructose as sole carbohydrate. Diabetes, Obesity and Metabolism. 2005;7(4):414-420.

59. Dhanabal SP, Kokate CK, Ramanathan M, Kumar EP, Suresh B. Hypoglycaemic activity of Pterocarpus marsupium Roxb. Phytotherapy Research. 2006:20(1):4-8.

60. Perera HKI, Handuwalage CS. Detection of protein glycation inhibitory potential of nine antidiabetic plants using a novel method. Asian Journal of Medical Sciences. 2014; 6(2):1-6.

61. Perera HKI, Handuwalage CS. Analysis of glycation induced protein cross-linking inhibitory effects of some antidiabetic plants and spices. BMC Complementary and Alternative Medicine. 2015; 15:175.

62. Pandey MC, Sharma VP. Hypoglycemic effect of bark of Pterocarpous marsupium Roxb. (Bijaka) on alloxan induced diabetes. Medicine and Surgery. 1975;15: 21.

63. Vats V, Grover J K, Rathi SS. Evaluation of antihyperglycemic and hypoglycaemic effect of Trigonella foenum-graecum Linn, Ocimum sanctum Linn and Pterocarpus marsupium Linn in normal and alloxanized diabetic rats. Journal of Ethnopharmacology. 2002; 79(1):95-100.

64. J.K. Grover, V. Vats and S.S. Yadav. Pterocarpus marsupium extract (Vijayasar) prevented the alteration in metabolic pattern induced in the normal rat by feeding an aqueous diet containing fructose as sole carbohydrate. Diabetes Obes Metab. 7(4): 414-420 (2005).

65. M.A.F. Jahromi and A.B. Ray. Antihyperlipidaemic effect of flavonoids from Pterocarpus marsupium. J Nat Prod. 56 (7): 989994 (1993).

66. Rane and Grampurohit N D, Hepatoprotective activity of Pterocarpus marsupium, and butea frondosa Ind j of Pharm Sci 1998; 5, 182-184.

67. Sapha B. Clinical observation of antidiabetic properties of Pterocarpus marsupium, Eugenia jambolona. J. Indian Med. Assoc. 1956; 27: 38890.

68. Gayathri $\mathrm{M}$ and Kannabiran K. Antimicrobial activity of Hemidesmus indicus, Ficus bengalensis and Pterocarpus marsupium roxb. Indian J. Pharm. Sci. 2009; 71: 578 -581.

69. Nair R, Kalariya T and Chanda S. Antibacterial activity of some selected Indian medicinal flora. Turk. J. Biol. 2005; 29: 41 -47.

70. Konda VGR, Madhavi E, Ruckmani A, Venkataramana $Y$. Int $J$ of Pharma \& Bio Sci, 2013; 4(4):729-740.

71. Jahromi MAF, Ray AB. J Nat Prod, 1993; 56(7):989-994.

72. Grover JK, Vats V, Yadav SS. Diabetes Obes Metab, 2005; 7(4):414-420.

73. Hougee S, Faber J, Sanders A, Hoijer MA, Smit HF. Planta Med, 2005, 71, 387-92.

74. Salunkhe VR, Yadav AV, Shete AS, Kane SR, Kulkarni AS. Indian Drugs, 2005; 42:319-321.

75. Halagappa K, Girish HN, Srinivasan BP. Indian J Pharmacol, 2010; 42:392-6.

76. Rajeeb M, Usman M, Pathan EKH, Jain BV, Pawar SR. J of Ph \& Sci Innov, 2012; 1-5.

77. Patil SK, Salunkhe VR, Ghumte DS, Mohite SK, Magdum CS. Int J of Phar Chem \& Bio Sci, 2012; 2(4):612-616.

78. Patil UH, Gaikwad KD "Microbicidal activity of stem f barks of Pterocarpus marsupium" International Journal of Pharma Sciences and Research, 2011, 2(1):36-40.

79. Vats V, Yadav SB, et al "Anti-cataract activity of Pterocarpus marsupium bark and trigonella foenum- gracecum seeds extract in alloxan diabetic rats" Journal of Ethnopharmacol, 2004, 93(2):289-294. 